Original scientific paper - Izvorni znanstveni rad

UDK: 637.352

\title{
Fatty acid profiles and mineral content of Serbian traditional white brined cheeses
}

\author{
doi: 10.15567/mljekarstvo.2018.0105 \\ Miroljub Barać* , Mirjana Kresojević, Bojana Špirović-Trifunović, Mirjana Pešić, \\ Tanja Vučić, Aleksandar Kostić, Saša Despotović \\ University of Belgrade, Faculty of Agriculture, Nemanjina 6, 11000 Belgrade, Serbia \\ Received - Prispjelo: 18.05.2017. \\ Accepted - Prihvaćeno: 17.12.2017.
}

\begin{abstract}
This study deals with fatty acid profiles and mineral contents of traditional Serbian white cheeses in brine. Study covered four Serbian traditional white brined cheeses: Zlatar cheese, Sjenica cheese, Svrljig cheese and Homolje cheese prepared from raw cow and ovine milk. Fatty acid profiles of traditional cheeses were qualitatively and quantitatively different. The content of saturated fatty acids was in the range of $65.97 \%-76.61 \%$ (cow cheeses) and $69.68 \%-74.52 \%$ (ovine cheeses). Unsaturated fatty acids range of cow and ovine cheeses was $23.39 \%-34.03 \%$ and $25.48 \%-30.08 \%$, respectively. Depending on the type of cheese, the ratio of polyunsaturated fatty acids was $1.66 \%-11.03 \%$. The lowest content of saturated fatty acids was observed in Sjenica cow cheeses. Thus, this type of traditional cheeses had the most favorable health indices including atherogenicity index (1.89), thrombogenicity index (1.37) and desirable fatty acid ratio (46.34\%). Mineral content of traditional cheeses was also different. The ratio $\mathrm{Ca}: \mathrm{P}$ was in the range of $0.70-1.33$. The highest level of $\mathrm{Ca}, \mathrm{P}, \mathrm{K}, \mathrm{Mg}, \mathrm{Zn}, \mathrm{Cu}$ and $\mathrm{Cr}$ was detected in Sjenica cheeses prepared from cow milk. The absence of $\mathrm{Cd}$ was observed in all cheeses.
\end{abstract}

Key words: white cheese, fatty acid profile, mineral content

\section{Introduction}

Cheese is a significant source of fat in the human diet and contains a high variety of fatty acids. From a nutritional point of view, different cheese varieties contain a highly digestible fat. Its digestibility is in the range of 88-94 \% (Renner, 1987). However, cheese is often presented by an adverse nutritional image due to the association between saturated fatty acids (SFAs), which are the major fatty acids of cheese, and cholesterol with cardiovascular diseases had. Although many researchers have considered SFAs as one of the contributory factors in heart disease, so far there has been no real study to demonstrate conclusively a direct link between cardiovascular disease and milk fat or to implicate dairy products in heart disease (Kanekanian, 2014). Moreover, cheese is a rich source of a short chain fatty acids and certain trans-fatty acids that can be considered as part of a healthy diet (Lock et al., 2014).

Cheese fat contains saturated (SFA), monounsaturated (MUFA) and polyunsaturated fatty acids (PUFA). In general, milk fat contains approximately $66 \%$ saturated (SFA) $(57.4 \%$ palmitic, $21.6 \%$ myristic, and $17.6 \%$ stearic), $30 \%$ monounsaturated (MUFA), and $4 \%$ polyunsaturated fatty acids (PUFA) (López-Expósito et al., 2012). Their ratio and composition in cheeses vary considerably, depending on the used milk and the method of manufacture (S anz Sampelyao et al, 2007; Domagala et al., 2010; MarkiewiczKęszycka et al., 2013). Most of them appear as esterified and part of them appears in a free form. 
Free fatty acids are usually released by the actions of lipases (from different sources) during lipolysis. They contribute directly to cheese flavour, particularly when they are properly balanced by products of proteolysis and by other reactions (Mallatou et al., 2003).

Besides proteins, fat and vitamins, cheese is a good source of minerals including calcium, sodium, potassium and magnesium. Cheese also contains a relatively large number of essential trace elements such as iron, iodine, copper, manganese, zinc, cobalt, selenium and chromium (Gordon, 2014). The level of minerals in cheese depends on numerous factors including those related to milk (type of milk, animal breed and period of lactation, feeding and geographical area of milk production) (Moreno-Rojas et al., 1994; Mendil, 2006), those related to the manufacturing processes and the specific variety of cheese (type of coagulation, pressing and salting conditions) (Prieto et al., 2002; Patińo et al., 2005; Anastasio et al., 2006; Mendil, 2006; GonzálezMartín et al., 2009; Jaoude et al., 2010; Gordon, 2014) and those related to possible contamination from the equipment during process (Yüzbaşi et al., 2003; 2009). Some of minerals like $\mathrm{Cu}, \mathrm{Zn}$ and $\mathrm{Fe}$ are essential micro nutrients and have a variety of biochemical functions in human body. But these elements can be toxic when taken in excess. Their necessity and toxicity is variable (Barać et al., 2015). In opposite, some heavy metals such as $\mathrm{Pb}$ and $\mathrm{Cd}$ present in cheese as contaminants are highly toxic, especially to children. Therefore, the levels of trace elements important for their nutritional and/or toxicological properties, in traditional dairy products such as cheeses, contribute to the characterization of the quality and adequacy of the Serbian diet.

White brined cheese usually named as "kriska cheese" is a traditional type of cheese in Serbia which is ripened and kept in brine. It can be manufactured from ovine, goat and cow milk or from any mixture of these sorts of milk. Due to different geographical areas of production, type of milk, animal breed and different autochthonous technological processes even though they belong to the same group of cheese, they have different phisico-chemi$\mathrm{cal}$, nutritive and sensory characteristics. More than $2 / 3$ of annual production and consumption of cheese in Serbia is related to this type of cheese. However, despite the high level of production, to the best of our knowledge, there is no report on the fatty acid profiles, mineral content and heavy metal content in those types of cheese. Thus, the aim of this work was to investigate and to compare the fatty acid profiles and the levels of trace metals and minerals in four Serbian traditional white brined cheeses. Concerning their role in the diet, comparative study of these compounds could better indicate the nutritional value of these products.

\section{Material and methods}

\section{Cheese samples}

This study covered four Serbian traditional white brined cheeses, Zlatar cheese (cow cheese), Sjenica cheeses (ovine and cow cheese), Svrljig cheese (ovine cheese) and Homolje cheeses (ovine and cow milk). Ripened (two months old) artisanal cheeses were collected (at least three different samples of each type of cheese from the same producer) from specific geographical area in period from April to September. The collected samples were transported to the laboratory in an isothermal container, lyophilized and kept at $-20^{\circ} \mathrm{C}$ until analysis.

\section{Analysis of fatty acids}

Amounts of $0.5 \mathrm{~g}$ of lyophilized cheese was extracted in $10 \mathrm{~mL}$ of heptane for 1 hour in ultrasound bath and then kept at room temperature for 24 hours. The extract was filtered through a filter paper Whatman No 1 and evaporated under nitrogen steam. The lipid compounds were dissolved in $1 \mathrm{~mL}$ hexane and converted to fatty acid methyl esters (FAME's) according to Kostić et al (2017) by using $1 \mathrm{~mL}$ of $14 \% \mathrm{BF}_{3} / \mathrm{MeOH}$ reagent. The mixture was heated at $100{ }^{\circ} \mathrm{C}$ for 1 hour, cooled to room temperature and methyl esters extracted in the hexane phase following addition of $1 \mathrm{~mL} \mathrm{H}_{2} \mathrm{O}$. The samples were centrifuged for $1 \mathrm{~min}$, and the upper hexane layer was removed then and concentrated under nitrogen.

FAME's were determined by capillary gas chromatography on GC instrument Agilent Technologies 6890 (USA) equipped with split/splitless injector, flame ionization detector (FID) and SP-2560 (length $100 \mathrm{~m}$, i.d. $0.25 \mathrm{~mm}$, film thickness $0.20 \mu \mathrm{m}$, Supelco, Bellefonte, USA). Injector and detector temperature were $250{ }^{\circ} \mathrm{C}$ and $260{ }^{\circ} \mathrm{C}$, respectively. As carrier gas, helium was used at flow rate of

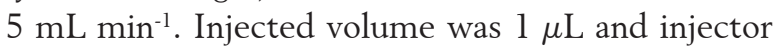
split ratio was set at 20:1. The column temperature 
was programmed from initial $50{ }^{\circ} \mathrm{C}$ (hold $5 \mathrm{~min}$ ) to $240{ }^{\circ} \mathrm{C}$ (hold $20 \mathrm{~min}$ ), with temperature rate of $4{ }^{\circ} \mathrm{C} \mathrm{min}^{-1}$. The total analysis time was $72.5 \mathrm{~min}$. The chromatographic peaks in the samples were identified by comparing relative retention times of FAME peaks with peaks in Supelco 37 Component FAME mix standard (Supelco, Bellefonte, USA). Fatty acid content was calculated in $\mathrm{mg} \mathrm{g}^{-1}$ of lipids and expressed in relative quantities as mass $\%$ of total fatty acids.

\section{Indexes of lipid quality}

From the fatty acid profiles of cheeses the unsaturated/saturated fatty acids (SFA/UFA) ratios and desirable fatty acids (DFA) were calculated. DFA was calculated according following equation:

$$
\mathrm{DFA}=\Sigma \mathrm{MUFA}+\Sigma \mathrm{PUFA}+\mathrm{C} 18: 0
$$

Also, to relate the profile of fatty acids with the risk of cardiovascular disorders, the atherogenicity index (AI) and thrombogenicity (TI) indices were calculated, as proposed by Ulbricht and Southgate (1991) through the equation:

$$
\begin{aligned}
A I= & {[(4 \times \mathrm{C} 14: 0)+\mathrm{C} 16: 0+\mathrm{C} 18: 0] / } \\
& \Sigma M U F A+\Sigma P U F A \\
T I= & (\mathrm{C} 14: 0+\mathrm{C} 16: 0+\mathrm{C} 18: 0) / \\
& (0.5 M U F A+0.5 P U F A-n 6+3 P U F A n 3+ \\
& \text { PUFA-n3/PUFA-n6) }
\end{aligned}
$$

$\mathrm{AI}$ indicates the relationship between the sum of the main saturated FAs and the main classes of unsaturated FAs. The former are considered as proatherogenic (favouring the adhesion of lipids to cells of the immunological and circulatory system), and the latter as anti atherogenic (inhibiting the aggregation of plaque and diminishing the levels of esterified fatty acid, cholesterol, and phospholipids, thereby preventing the appearance of micro- and macrocoronary diseases) (Prandini et al, 2011). TI expresses the tendency to form clots in the blood vessels. It is defined as the relationship between the pro-thrombogenetic (saturated) and the anti-thrombogenetic fatty acids (MUFAs, PUFAs - n6 and PUFAs - n3) (Garaffo et al., 2011).

\section{Mineral profiles of Serbian traditional white cheeses in brine}

The mineral content in traditional cheeses was analysed by atomic absorption spectroscopy (AAS)
(Varian Spectra AA 220). Contents of microelements $\mathrm{Fe}, \mathrm{Mn}, \mathrm{Cu}, \mathrm{Zn}, \mathrm{Cr}, \mathrm{Pb}, \mathrm{Co}$ and $\mathrm{Cd}$ in lyophilized cheeses were analysed after the destruction in concentrated $\mathrm{HNO}_{3}$ and $\mathrm{HClO}_{4}$ with the addition of $33 \% \mathrm{H}_{2} \mathrm{O}_{2}$ by wet ashing (Jonas and Case, 2001). Contents of $\mathrm{Ca}$ and $\mathrm{Mg}$ were detected after the destruction with concentrated acids $\mathrm{HNO}_{3}$ and $\mathrm{HCl}$ by dry ashing (Jones and Case, 1990). Contents of $\mathrm{P}, \mathrm{K}$, and $\mathrm{Na}$ in lyophilized samples were determined after the destruction with concentrated acids $\mathrm{H}_{2} \mathrm{SO}_{4}$ and $\mathrm{HClO}_{4}$ by dry ashing. Phosphorus was determined by the colorimetric method, whereas $\mathrm{K}$ and $\mathrm{Na}$ were determined by the flame-photometry method (Jones, 2001).

\section{Statistical analysis}

All measurements were done in triplicate. Data were subjected to one-way analysis of variance (ANOVA) with Microsoft Office Excel ver. 7.0 and the comparison of the mean values was done by Tuckey's test at $\mathrm{p}<0.05$. Mineral contents were correlated with each other by Person two-tailed significance correlation at $\mathrm{p}<0.05$ level.

\section{Results and discussion}

Fatty acids profiles of traditional Serbian white brined cheeses

Fatty acid profiles of white brined Serbian cheeses are shown in Table 1. Under experimental conditions used in this study, up to twenty one fatty acids were detected depending on the cheese variety. Twelve of them were saturated whereas up to nine were unsaturated, monounsaturated (MUFA) and polyunsaturated (PUFA) acids.

In general, fatty acid profiles of traditional white cheeses were similar qualitatively, especially regarding to saturated fatty acids. More precisely, the presence of henicosanoic acid (C21:0) in both types of Sjenica cheeses was the only qualitative difference in comparison to Homolje, Zlatar and Svrljig cheeses. More pronounced qualitative differences can be observed in the case of unsaturated fatty acids (USFA). For example, cis-10-pentadecanoic acid (C15:1) was found only in Zlatar cheese whereas linoleaidic acid (C18:2n6t) was detected only in ovine cheese from Svrljig. Such profiles were in good agreement with data reported in literature for other types of cheeses 
(Domagala et al., 2009; Aguilar et al., 2014). As the cheeses were sampled during the same season (spring-summer), the absence of certain fatty acids could be attributed to initial fatty acid composition of milk, influenced by milk origin, breed, stage of lactation and animal diet (Walstra and Jenness, 1984; Zeppa et al., 2003; Sanz Sampelayo et al., 2007; Heck et al., 2009) as well as to differences in lipid metabolism of autochthonous microbial cultures (McSweeney and Sousa, 2000).

As expected, white brined cheeses like other types of cheeses are good sources of both, saturated and unsaturated fatty acids. However, SFA dominated in fatty acid profiles of all traditional white brined cheeses. Their content varied significantly $(\mathrm{p}<0.05)$ depending on cheese variety and ranged from $65.97 \%$ to $76.61 \%$ (cow cheeses) and $69.68 \%$ to $74.52 \%$ (ovine cheese, Table 2). The lowest content of SFA was observed in Sjenica cow cheese whereas the highest ratio of these fatty acids was in Homolje cow cheese. The most abundant saturated fatty acids in all cheeses were palmitic (C16:0) acid, stearic (C18:0) acid, and miristic (C14:0) acid. These fatty acids constituted $18.36 \%-22.48 \%$, $9.91 \%-12.31 \%$ and $10.78 \%-11.95 \%$ of all identified fatty acids of cow cheeses, respectively. In ovine cheeses major SFA`s, C16:0, C18:0, C14:0, were in the range of $18.06 \%-21.11 \%, 9.45 \%-13.22 \%$ and $11.78 \%-12.38 \%$, respectively.

Based on the length of the hydrocarbon chain SFAs of cheese are usually classified as short-chain (C4-C6), medium-chain (C8-C14), and long-chain $(\geq \mathrm{Cl}$ ) fatty acids. According to this classification, SFAs of traditional cheeses are composed of $52.02 \%-62.42 \%$ of long chain SFAs, $4.37 \%-7.38 \%$ of short and $31.42 \%-41.53 \%$ of medium chain SFAs. As expected ovine cheeses had higher ratio of short fatty acids then cow cheeses (6.31\%-7.38\%), with the exception of Sjenica cow cheese in which short-chain FAs represented $6.38 \%$ of total SFAs.

Table 1. Fatty acid content of traditional Serbian white brined cheeses (\%)

\begin{tabular}{|c|c|c|c|c|c|c|}
\hline \multirow[b]{3}{*}{ Saturated fatty acid (\%) } & \multicolumn{6}{|c|}{ White cheese in brine } \\
\hline & \multicolumn{3}{|c|}{ Ovine cheeses } & \multicolumn{3}{|c|}{ Cow cheeses } \\
\hline & Svrljig & Homolje & Sjenica & Homolje & Sjenica & Zlatar \\
\hline C4:0 butiric & $2.51 \pm 0.21^{\mathrm{a}}$ & $2.26 \pm 0.15^{\mathrm{a}, \mathrm{b}}$ & $2.12 \pm 0.05^{b}$ & $1.54 \pm 0.09^{c}$ & $2.17 \pm 0.10^{\mathrm{b}}$ & $1.51 \pm 0.06^{c}$ \\
\hline C6:0 caproic & $2.63 \pm 0.03^{a}$ & $2.44 \pm 0.09^{b}$ & $2.39 \pm 0.05^{b}$ & $1.81 \pm 0.10^{\mathrm{c}, \mathrm{d}}$ & $2.04 \pm 0.03^{c}$ & $1.62 \pm 0.10^{\mathrm{d}}$ \\
\hline C8:0 caprilic & $2.12 \pm 0.11^{\mathrm{b}}$ & $2.38 \pm 0.22^{b}$ & $2.40 \pm 0.12^{\mathrm{b}}$ & $1.38 \pm 0.10^{c}$ & $1.28 \pm 0.17^{\mathrm{c}}$ & $1.13 \pm 0.08^{\mathrm{c}}$ \\
\hline Cl0:0 capric & $5.02 \pm 0.14^{b}$ & $7.12 \pm 0.21^{\mathrm{a}}$ & $7.36 \pm 0.32^{\mathrm{a}}$ & $3,44 \pm 0.17^{c}$ & $2,69 \pm 0.11^{\mathrm{d}}$ & $2,59 \pm 0.20^{\mathrm{d}}$ \\
\hline $\mathrm{Cl2:0}$ lauric & $3.81 \pm 0.05^{\mathrm{a}}$ & $4.02 \pm 0.10^{\mathrm{a}}$ & $4.06 \pm 0.11^{\mathrm{a}}$ & $3.33 \pm 0.01^{c}$ & $2.93 \pm 0.08^{\mathrm{b}}$ & $3.06 \pm 0.02^{\mathrm{b}}$ \\
\hline Cl4:0 miristic & $11.78 \pm 0.25^{\mathrm{b}}$ & $11.95 \pm 0.27^{b}$ & $12.38 \pm 0.09^{a}$ & $11.95 \pm 0.13^{b}$ & $10.78 \pm 0.10^{c}$ & $11.88 \pm 0.22^{c}$ \\
\hline C15:0 pentadecanoic & $2.78 \pm 0.04^{\mathrm{d}}$ & $2.94 \pm 0.07^{\mathrm{c}}$ & $2.84 \pm 0.10^{c}$ & $5.34 \pm 0.23^{a}$ & $3.05 \pm 0.06^{\mathrm{c}}$ & $4.0 \pm 0.16^{\mathrm{b}}$ \\
\hline Cl6:0 palmitic & $21.11 \pm 0.15^{\mathrm{b}}$ & $18.06 \pm 0.24^{c}$ & $18.08 \pm 0.09^{c}$ & $20.56 \pm 0.10^{\mathrm{b}}$ & $18.36 \pm 0.26^{c}$ & $22.48 \pm 0.19^{a}$ \\
\hline Cl7:0 heptadecanoic & $2.36 \pm 0.08^{\mathrm{c}}$ & $2.46 \pm 0.15^{c}$ & $2,68 \pm 0.10^{c}$ & $4.29 \pm 0.21^{\mathrm{a}}$ & $2.73 \pm 0.26^{\mathrm{c}}$ & $3.35 \pm 0.15^{b}$ \\
\hline C18:0 stearic & $9.45 \pm 0.21^{f}$ & $13.22 \pm 0.24^{\mathrm{a}}$ & $10.05 \pm 0.10^{\mathrm{d}}$ & $11.06 \pm 0.16^{\mathrm{c}}$ & $12.31 \pm 0.22^{b}$ & $9.91 \pm 0.31^{\mathrm{d}, \mathrm{f}}$ \\
\hline C21:0 henicosanoic & n.d. ${ }^{\mathrm{b}}$ & n.d. ${ }^{\mathrm{b}}$ & $1.66 \pm 0.09^{\mathrm{a}}$ & n.d. ${ }^{\mathrm{b}}$ & $1.56 \pm 0.04^{\mathrm{a}}$ & n.d. ${ }^{\text {b }}$ \\
\hline C22:0 behenic & $6.11 \pm 0.14^{\mathrm{c}}$ & $7.67 \pm 0.11^{\mathrm{a}}$ & $3.9 \pm 0.12^{\mathrm{d}}$ & $1.54 \pm 0.09^{c}$ & $6.07 \pm 0.15^{c}$ & $6.91 \pm 0.24^{b}$ \\
\hline \multicolumn{7}{|l|}{ Unsaturated fatty acids (\%) } \\
\hline Cl4:1 miristoleic & n.d. ${ }^{e}$ & $1.41 \pm 0.05^{\mathrm{d}}$ & $1.64 \pm 0.0 .08^{c}$ & $2.46 \pm 0.07^{\mathrm{a}}$ & $1.84 \pm 0.02^{\mathrm{b}}$ & $2.40 \pm 0.11^{\mathrm{a}}$ \\
\hline C15:1 cis-10-pentadecanoic & n.d. ${ }^{b}$ & n.d. ${ }^{b}$ & n.d. ${ }^{\mathrm{b}}$ & n.d. ${ }^{\mathrm{b}}$ & n.d. ${ }^{\mathrm{b}}$ & $1.18 \pm 0.09^{\mathrm{a}}$ \\
\hline Cl6:1 palmitoleic & n.d. ${ }^{f}$ & n.d. & $1.16 \pm 0.10^{\mathrm{d}}$ & $1.56 \pm 0.05^{\mathrm{c}}$ & $2.04 \pm 0.07^{b}$ & $2.59 \pm 0.10^{\mathrm{a}}$ \\
\hline C18:ln9c (oleic) & $11.05 \pm 0.24^{\mathrm{e}}$ & $10.26 \pm 0.15^{f}$ & $14.34 \pm 0.31^{\mathrm{d}}$ & $6.63 \pm 0.31^{g}$ & $16.62 \pm 0.24^{\mathrm{a}}$ & $15.55 \pm 0.32^{\circ}$ \\
\hline C18: $\ln 9 t$ (elaidic) & $7.4 \pm 0.23^{c}$ & $11.29 \pm 0.15^{\mathrm{a}}$ & $9.38 \pm 0.11^{\mathrm{b}}$ & $11.08 \pm 0.12^{\mathrm{a}}$ & $9.81 \pm 0.21^{b}$ & $6.73 \pm 0.18^{\mathrm{d}}$ \\
\hline C18:2n6c linoleic & $3.83 \pm 0.12^{\mathrm{a}}$ & $2.52 \pm 0.17^{\mathrm{d}}$ & $3.13 \pm 0.10^{c}$ & $1.20 \pm 0.08^{\mathrm{e}}$ & $3.38 \pm 0.09^{b}$ & $3.11 \pm 0.10^{\mathrm{c}}$ \\
\hline C18:2n6t linoleaidic & $4.55 \pm 0.21^{\mathrm{a}}$ & n.d. ${ }^{b}$ & n.d. ${ }^{b}$ & n.d. ${ }^{b}$ & n.d. ${ }^{b}$ & n.d. ${ }^{\mathrm{b}}$ \\
\hline $\mathrm{C} 18: 3 \mathrm{n} 6 \gamma$-linoleic & n.d. ${ }^{c}$ & n.d. ${ }^{c}$ & $0.43 \pm 0.03^{a}$ & $0.46 \pm 0.02^{\mathrm{a}}$ & $0.34 \pm 0.01^{\mathrm{b}}$ & n.d. ${ }^{c}$ \\
\hline C20: $\ln 9$ cis-1 1-eicosenoic & $2.65 \pm 0.01^{\mathrm{a}}$ & n.d. ${ }^{b}$ & n.d. ${ }^{b}$ & n.d. ${ }^{b}$ & n.d. ${ }^{b}$ & n.d. ${ }^{b}$ \\
\hline
\end{tabular}

* values represent means $\pm \mathrm{SD}$; values with the same letter whitin the same row are not statistically significant at $\mathrm{p}>0.05$; n.d. - not detected 
Long-chain saturated fatty acids dominated in cow cheeses. Their ratio was almost identical (62.20 \%-62.42 \% of total SFA). Significantly $(\mathrm{p}<0.05)$ lower ratio of these fatty acids was observed in ovine chesses (52.02 \%-56.01\%).

SFAs have a poor image because there is some evidence of negative influence on blood lipids. However, despite the presence of considerable amounts of these fatty acids, there is no clear evidence relating cheese consumption to any disease. It is also known that individual SFAs influence blood cholesterol level differently (Legrand and Rioux, 2010). Total plasma cholesterol raising effects of SFAs are generally greater with medium chain lengths acids (C12:0, C14:0) than for those with longer chain lengths (C16:0 and C18:0) (German and Dillard, 2006). According to Parodi (2009) C12:0 is more potent than $\mathrm{C} 14: 0$ and $\mathrm{C} 16: 0$, but it's ratio was only $2.93 \%-3.33 \%$ (cow cheeses) and $3.81 \%-4.06 \%$ (ovine cheeses) of all detected FAs (Table 1). It is believed that the other saturated fatty acids found in cheese neutralize their effect since they increase HDL- level (Parodi, 2009). C18:0, which is an important component of the SFAs in traditional cheeses (represented $13.56 \%-18.66 \%$ of SFAs), is rapidly converted to the MUFA oleic acid (C18:1), which is considered to be one of the healthier sources of fat in diet and is not related with cardiovascular risk (Jakobsen et al., 2009). In addition, short chain SFAs (C4-C6) and some of MSFAs (C8-C10) represented $6.85-14.27 \%$ of all FA of traditional cheeses. Ovine chesses had higher content of these acids than cow cheeses $(12.08 \%-14.27 \%$ comparing to $6.85 \%-8.18 \%$ ). These SFAs are highly digestible as they are preferentially hydrolysed from the triglycerides and are directly transferred from the intestine to the portal circulation without re-synthesis of triglycerides (Sanz Sampelayo et al., 2007). Thus, there is only a low tendency of adipose formation. These acids contribute to reducing of cholesterol level in serum and liver as well as triglyceride levels (Sanz Sampelayo et al., 2007). It has also been shown in vivo that butyric acid (C4:0) is a stimulant of normal colonic cell proliferation and it can also inhibit growth and proliferation of colon cancer cell lines (Aluko, 2012) whereas caprylic acid (C8:0) and capric acid (C10:0) expressed antiviral and antibacterial properties (Nair et al., 2005).

The ratio of USFAs of traditional cheeses which are composed of MUFAs and PUFAs was quite different $(\mathrm{p}<0.05)$ and it was found to be in the range of $23.39 \%-34.03 \%$ (Table 2). The largest part of USFAs was accounted for MUFAs and among them C18:1 acid is characterized by the highest content $(17.71 \%-26.43 \%)$ which is in a good agreement with data reported for milk (MarkiewiczKęszycka et al., 2013) and other types of cheeses (Domagała et al., 2010). But, in traditional cheeses this acid existed as two geometric isomers, oleic acid $(\mathrm{Cl} 8: \ln 9 \mathrm{c})$ and elaidic acid $(\mathrm{Cl} 8: \ln 9 \mathrm{t})$ and their share in some of cheeses was quite different. While in ovine cheese from Homolje their ratio was almost

Table 2. Health lipid indices of traditional Serbian white brined cheeses*

\begin{tabular}{ccccccc}
\hline \multirow{2}{*}{ Parameters } & \multicolumn{5}{c}{ White cheese in brine } \\
\cline { 2 - 7 } & \multicolumn{5}{c}{ Ovine cheeses } \\
\cline { 2 - 7 } & Svrljig & Homolje & Sjenica & Homolje & Sjenica & Zlatar \\
\hline SFA & $69.68^{\mathrm{c}}$ & $74.52^{\mathrm{b}}$ & $69.92^{\mathrm{c}}$ & $76.61^{\mathrm{a}}$ & 65.97 & $68.44^{\mathrm{d}}$ \\
\hline SCSFA C4:0-C6:0 & $5.14^{\mathrm{a}}$ & $4.70^{\mathrm{b}}$ & $4.51^{\mathrm{c}}$ & $3.35^{\mathrm{e}}$ & $4.21^{\mathrm{d}}$ & $3.13^{\mathrm{f}}$ \\
\hline MCFA C8:0-C15:0 & $25.51^{\mathrm{c}}$ & $28.41^{\mathrm{b}}$ & $29.04^{\mathrm{a}}$ & $25.44^{\mathrm{c}}$ & $20.73^{\mathrm{e}}$ & $22.66^{\mathrm{d}}$ \\
\hline LCSFAC 16:0-C24:0 & $39.03^{\mathrm{e}}$ & $41.41^{\mathrm{b}}$ & $36.37^{\mathrm{g}}$ & $47.82^{\mathrm{a}}$ & $41.03^{\mathrm{f}}$ & $42.65^{\mathrm{c}}$ \\
\hline MUFA & $18.45^{\mathrm{e}}$ & $22.96^{\mathrm{d}}$ & $26.52^{\mathrm{c}}$ & $21.73^{\mathrm{d}}$ & $30.31^{\mathrm{a}}$ & $28.45^{\mathrm{b}}$ \\
\hline PUFA & $11.03^{\mathrm{a}}$ & $2.52^{\mathrm{e}}$ & $3.56^{\mathrm{c}}$ & $1.66^{\mathrm{f}}$ & $3.72^{\mathrm{b}}$ & $3.11^{\mathrm{d}}$ \\
\hline DFA & $38.93^{\mathrm{d}}$ & $38.7^{\mathrm{d}}$ & $40.13^{\mathrm{c}}$ & $34.45^{\mathrm{e}}$ & $46.34^{\mathrm{a}}$ & $41.47^{\mathrm{b}}$ \\
\hline AI & $2.44^{\mathrm{c}}$ & $2.74^{\mathrm{b}}$ & $2.38^{\mathrm{e}}$ & $3.06^{\mathrm{a}}$ & $1.89^{\mathrm{e}}$ & $2.31^{\mathrm{d}}$ \\
\hline TI & $1.87^{\mathrm{b}}$ & $1.84^{\mathrm{b}}$ & $1.51^{\mathrm{d}}$ & $2.12^{\mathrm{a}}$ & $1.37^{\mathrm{e}}$ & $1.64^{\mathrm{c}}$ \\
\hline USFA/SFA & $0.42^{\mathrm{c}}$ & $0.34^{\mathrm{d}}$ & $0.43^{\mathrm{c}}$ & $0.30^{\mathrm{d}}$ & $0.51^{\mathrm{a}}$ & $0.46^{\mathrm{b}}$ \\
\hline
\end{tabular}

*data were presented as average values; values with the same letter whitin the same row are not statistically significant at $\mathrm{p}>0.05$; AI - atherogenicity index; TI - thrombogenicity index 
identical, in Homolje cow cheeses elaidic acid dominated (Table 1). In other cheeses oleic acid was the most abundant MUFA.

PUFAs are significant part of identified fatty acids of investigated cheeses. Depending on the type of cheese, their ratios were $11.03 \%$ to $1.66 \%$ (Table 2). The highest content of these fatty acids was detected in ovine Homolje cheese due to presence of linoleaidic (C18:2n6t; $4.55 \%)$ and C20: $\ln 9$ cis-11-eicosenoic acids (2.56 \%). These PUFAs were not detected in other cheeses and the major polyunsaturated fatty acid in all other cheeses was linoleic (C18:2n6c). Under conditions used in this study, due to absence of standards, CLAs were not detected and quantified.

As a result of different fatty acid compositions, white brined cheeses are characterized by significantly $(\mathrm{p}<0.05)$ different health lipid indices including index of atherogenicity (IA), index of thrombogenicity (IT), desirably fatty acids ratio (DFA) and USFA/SFA ratio (Table 2). Due to the lowest content of USFAs (23.39\%) Homolje cow cheese is characterized with the most unfavorable DFA, AI-, TI- values and USFA/SFA ratio. In opposite to this, the best health lipid indices had cow cheese from Sjenica (AI 1.89; TI 1.37 and DFA $46.34 \%$ ).

\section{Mineral profiles of Serbian white brined cheeses}

Table 3 presents the mean content of calcium, phosphorus, magnesium, potassium, sodium, and heavy metals (iron, zinc, copper, leads, cadmium, chromium, cobalt and nickel) found in traditional Serbian white cheeses. Mineral contents of these cheeses differed significantly $(p<0.05)$. Calcium and phosphorus were the most abundant in Zlatar and Sjenica cheeses made from cow milk whereas their lowest content was registered in Sjenica ovine cheese. These results were in good agreement with data reported by González-Martín et al. (2009) but did not coincide with data reported by RaynalLjutovac et al. (2008) which showed that these two elements were more abundant in ovine than in cow milk. The ratio Ca:P in these cheeses was in the range of 0.7-1.33. Cow cheeses as well as Homolje ovine cheeses had this ratio in the range considered to be normal (Jennes, 1980) whereas the other cheeses had slightly lower ratios of $\mathrm{Ca}$ and $\mathrm{P}$. Contents of $\mathrm{K}, \mathrm{Mg}$ and $\mathrm{Na}$ also varied and were in the range of $124.5-290.4 \mathrm{mg} / 100 \mathrm{~g}$. 23.20-34.78 mg/100 g and $1570-4400 \mathrm{mg} / 100 \mathrm{~g}$ of lyophilized cow cheese, and $124.5-265.6 \mathrm{mg} / 100 \mathrm{~g}, 24.73-31.84 \mathrm{mg} / 100 \mathrm{~g}$ and $1400-6220 \mathrm{mg} / 100 \mathrm{~g}$ of lyophilized ovine cheese, respectively. The highest content of $\mathrm{K}$ and $\mathrm{Mg}$ was observed in cow cheese from Sjenica.

Significant differences in $\mathrm{Zn}$ and heavy metals contents were also observed. For example, $\mathrm{Zn}$ content was in the range of 20.73 to $47.11 \mu \mathrm{g} / \mathrm{g}$ (cow cheeses) and 16.19 to $23.45 \mu \mathrm{g} / \mathrm{g}$ (ovine cheeses), whereas Fe content was 5.81-8.08 $\mu \mathrm{g} / \mathrm{g}$ (cow cheeses) and 2.95-9.62 $\mu \mathrm{g} / \mathrm{g}$ (ovine cheeses) as presented in Table 3. However, detected values were in agreement with data reported for other types of cheeses (Cichoscki et al., 2002; Herrera et al., 2006; González-Martín et al, 2009).

$\mathrm{Pb}$ content of investigated cheeses was approximately three to five times lower than those detected in Turkish white brined cheeses (Ayar et al., 2005, 2009) and Italian ovine cheeses (Anastasio et al., 2006). The highest level of $\mathrm{Pb}$ was detected in ovine cheeses from Sjenica whereas the lowest level was in ovine cheeses from Homolje. Lead presence in these

Table 3. Mineral and heavy metal content of traditional Serbian white cheeses in brine

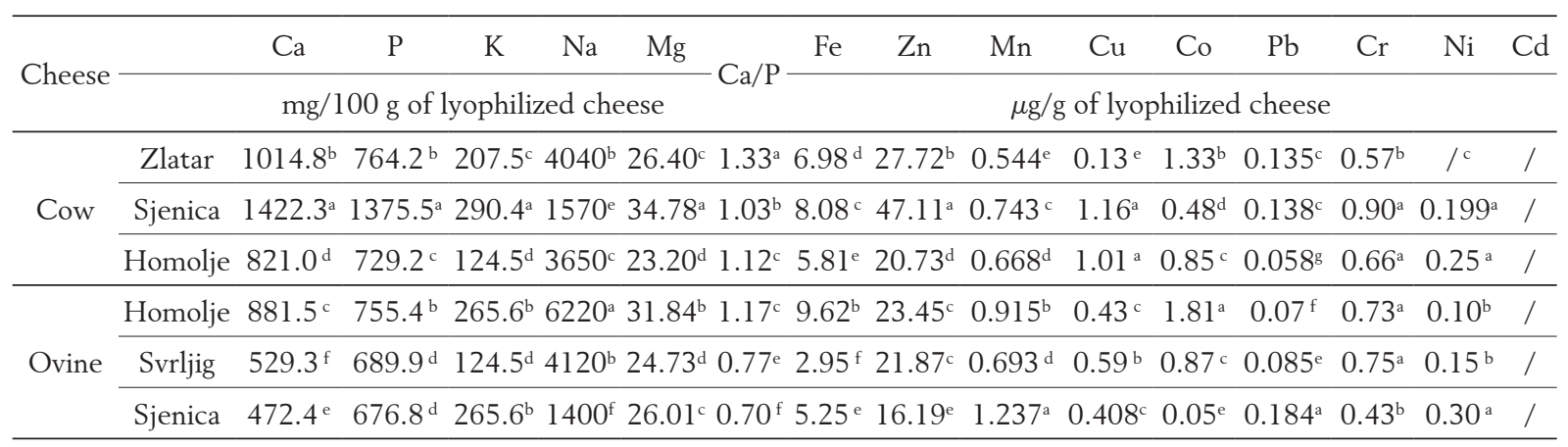

\footnotetext{
$* *$ values represent means of three measurements; values with the same letter whitin the same column are not statistically significant
} at $\mathrm{p}<0.05$ 
cheeses could be a result of contamination from environment during the cheese making process. Lead, due to its wide use in industrial processes, ranks as the metal of largest diffusion through the atmosphere (SEMA, 1998). This could in part explain concentrations detected in investigated cheeses produced in mountain areas of Sjenica, Homolje, Zlatar and Svrljig which are relatively far from the urban areas and industrial plants. In addition, cadmium was not detected in investigated cheeses. The observed variations of minerals and heavy metals content could be attributed to numerous factors including type of milk, animal breed, period of lactation, feeding. Variations in technological production process (especially pressing and salting) in different production regions and among households result in different $\mathrm{pH}$ values of cheeses which have effect on different distribution of minerals and metals into cheese/whey or brine (Gordon, 2014).

The correlations between elements were studied and the results are shown in Table 4. The concentration of $\mathrm{Ca}$ was positively correlated $(\mathrm{p}<0.05)$ with $\mathrm{P}, \mathrm{Mg}$ and $\mathrm{Zn}$ which is in agreement with investigations of several authors (Moreno-Rojas et al., 1994; Gambelli et al.,1999; González-Martín et al., 2009). Also, Ca concentration was positively correlated with $\mathrm{Cr}$ concentration. In addition, González-Martín et al. (2009) found a positive correlation between concentrations of $\mathrm{Na}$ and $\mathrm{P}$ and a negative correlation between $\mathrm{Na}$ and $\mathrm{Zn}$ concentrations. In the present investigation a significant correlation was found only between $\mathrm{Na}$ and $\mathrm{Co}$. Iron, nickel and lead were minerals that were not correlated to other minerals in the study.

\section{Conclusion}

Results of this investigation suggest significant differences in fatty acid profiles and mineral content of Serbian traditional white cheeses in brine. The most favorable fatty acid composition and health lipid indices including index of atherogenicity, index of thrombogenicity, desirably fatty acids ratio and USFA/SFA ratio had Sjenica cheese prepared from cow milk. Sjenica cow cheese is also characterized with the highest concentration of $\mathrm{Ca}, \mathrm{P}, \mathrm{K}, \mathrm{Mg}, \mathrm{Zn}$, $\mathrm{Cu}$ and $\mathrm{Cr}$. Hence, among the investigated cheeses, Sjenica cheese had the most favorable impact on human health. This could be attributed to several factors including breed, feed, geographical position and production process. Investigated cheeses had low levels of $\mathrm{Pb}$ whereas absence of cadmium was detected in all cheese samples. Results of our study clearly highlighted significant importance of white brined cheese role in healthy human diet.

\section{Acknowledgement}

This work was supported by the Serbian Ministry of Education, Science and Technological Development.

Table 4. Correlation coefficients between minerals and metals of Traditional cheeses

\begin{tabular}{|c|c|c|c|c|c|c|c|c|c|c|c|c|c|}
\hline & $\mathrm{Ca}$ & $\mathrm{P}$ & $\mathrm{k}$ & $\mathrm{Na}$ & $\mathrm{Mg}$ & $\mathrm{Fe}$ & $\mathrm{Zn}$ & $\mathrm{Mn}$ & $\mathrm{Cu}$ & Co & $\mathrm{Pb}$ & $\mathrm{Cr}$ & $\mathrm{Ni}$ \\
\hline $\mathrm{Ca}$ & 1.00 & $0.89^{*}$ & 0.48 & 0.09 & $0.79 *$ & -0.10 & $0.92^{*}$ & -0.21 & -0.32 & 0.15 & -0.15 & $0.72^{*}$ & -0.07 \\
\hline $\mathrm{P}$ & & 1.00 & 0.55 & -0.19 & $0.82^{*}$ & -0.17 & $0.97^{*}$ & -0.01 & -0.14 & -0.21 & 0.07 & $0.72^{*}$ & 0.20 \\
\hline $\mathrm{K}$ & & & 1.00 & -0.18 & $0.72^{*}$ & 0.17 & 0.48 & 0.54 & 0.38 & -0.10 & 0.48 & 0.19 & 0.08 \\
\hline $\mathrm{Na}$ & & & & 1.00 & 0.24 & -0.24 & -0.08 & -0.14 & -0.44 & $0.82 *$ & -0.67 & 0.41 & -0.25 \\
\hline $\mathrm{Mg}$ & & & & & 1.00 & -0.32 & 0.80 & 0.30 & 0.00 & 0.07 & 0.00 & $0.82^{*}$ & 0.21 \\
\hline $\mathrm{Fe}$ & & & & & & 1.00 & -0.17 & -0.28 & -0.27 & 0.30 & 0.05 & -0.63 & -0.59 \\
\hline $\mathrm{Zn}$ & & & & & & & 1.00 & -0.18 & -0.30 & -0.06 & 0.04 & $0.74^{*}$ & 0.04 \\
\hline $\mathrm{Mn}$ & & & & & & & & 1.00 & $0.86^{*}$ & -0.44 & 0.39 & 0.03 & 0.65 \\
\hline $\mathrm{Cu}$ & & & & & & & & & 1.00 & -0.65 & 0.61 & -0.24 & 0.55 \\
\hline $\mathrm{Co}$ & & & & & & & & & & 1.00 & -0.62 & 0.09 & -0.70 \\
\hline $\mathrm{Pb}$ & & & & & & & & & & & 1.00 & -0.38 & 0.18 \\
\hline $\mathrm{Cr}$ & & & & & & & & & & & & 1.00 & 0.30 \\
\hline $\mathrm{Ni}$ & & & & & & & & & & & & & 1.00 \\
\hline
\end{tabular}

${ }^{*}$ These correlation coefficients correspond to correlations that are significant at $\mathrm{p}<0.05$. 


\section{Profili masnih kiselina $i$ udjeli mineralnih tvari tradicionalnih bijelih sireva Srbije}

\section{Sažetak}

Istraživanje se bavi profilima masnih kiselina i udjelom mineralnih tvari tradicionalnih bijelih sireva Srbije. Istraživanja se odnose na četiri tradicionalna sira Srbije: Svrljiški, Zlatarski, Sjenički i Homoljski bijeli sir koji su pripremljeni od sirovog kravljeg i ovčjeg mlijeka. Profili masnih kiselina tradicionalnih sireva bitno su različiti kako u kvalitativnom tako i u kvantitativnom smislu. Sadržaj zasićenih masnih kiselina bio je u rasponu 65,97 \%-76,61 \% za kravlje i 69,68 \%-74,52 \% za ovčje sireve. Nezasićene masne kiseline činile su 23.39 \%-34.03 \% (ovčji sirevi), odnosno 25.48 \%-30.08 \% (kravlji sirevi) identificiranih masnih kiselina. Ovisno o vrste sira, udjel masnih kiselina iznosio je 1,66 \%-11,03\%. Najniži udjel zasićenih masnih kiselina utvrđen je u Sjeničkom kravljem siru. Stoga je ovaj tip tradicionalnog sira imao i najpovoljnije zdravstvene pokazatelje poput AI, $(1,89)$, TI $(1,37)$ i udjela poželjnih masnih kiselina (46.34\%). Također, ispitivani sirevi odlikuju se značajno različitim sadržajem mineralnih tvari. Odnos Ca:P bio je u rasponu 0,70-1,33. Najviši udjeli Ca, P, K, Mg, Zn, Cu i Cr utvrđeni su u Sjeničkom kravljem siru. Ovi sirevi nisu sadržali Cr.

Ključne riječi: bijeli sir, profil masnih kiselina, sadržaj minerala

\section{References}

1. Aguilar, C., Toro-Mujica, P., Vargas-Bello-Pérez, E., Vera, R., Ugalde, C., Rodríguez, S., Briones, I. (2014): A comparative study of the fatty acid profiles in commercial sheep cheeses. Grasas Aceites 65(4), 048-056.

2. Aluko, R. (2012): Functional Foods and Nutraceuticals, Springer New York, 1-155.

3. Anastasio, A., Caggiano, R., Macchiato, M., Catellani, P., Ragosta, M., Paino,S., Cortesi, M.L. (2006): Heavy Metal Concentrations in Dairy Products from Sheep Milk Collected in Two Regions of Southern Italy. Acta Veterinaria Scandinavica 47, 69-74. https://doi.org/10.1186/1751-0147-47-69

4. Ayar, A., Sert, D. (2005): The important of milk and dairy products in society nutrition. Food and Food Technology 7, 1-5.

5. Ayar, A., Sert, D., Akın, N. (2009): The trace metal levels in milk and dairy products consumed in middle Anatolia-Turkey, Environ Monit Assess 152, 1-12. https://doi.org/10.1007/s10661-008-0291-9
6. Barać, M., Pešić, M., Kostić, A. (2015): Biologically active food components, Faculty of Agriculture, University of Belgrade.

7. Cichoscki, A., Valduga, E., Valduga, A., Tornadijo, M., Fresno, J. (2002): Characterization of Prato cheese, a Brazilian semi-hard cow variety: evolution of physico-chemical parameters and mineral composition during ripening. Food Control 13, 329-336. https://doi.org/10.1016/S0956-7135(02)00039-7

8. Domagała, J., Sady, M., Grega, T., Pustkowiak, H., Florkiewicz, A. (2010): The influence of cheese type and fat extraction method on the content of conjugated linoleic acid. Journal of Food Composition and Analysis 23, 238-243. https://doi.org/10.1016/j.jfca.2009.11.002

9. Gambelli, L., Belloni, P., Ingrao, G., Pizzoferrato, L., Santaroni, G.P. (1999): Mineral and trace elements in some Italian dairy products. Journal of Food Composition and Analysis 12, 27-35. https://doi.org/10.1006/jfca.1998.0802

10. Garaffo, M.A., Vassallo-Agius, R., Nengas, Y., Lembo, E., Rando, R. (2011): Fatty acids profile, atherogenic (IA) and thrombogenic (IT) health lipid indices, of raw roe of Blue Fin Tuna (Thunnus thynnus L.) and Their Salted Product "Bottarga". Food Nutrition Sciences 2, 736-743. https://doi.org/10.4236/fns.2011.27101

11. German, J.B., Dillard, C.J. (2006): Composition, structure and absorption of milk lipids: a source of energy, fatsoluble nutrients and bioactive molecules. Critical Review in Food Science and Nutrition 46, 57-92. https://doi.org/10.1080/10408690590957098

12. González-Martín, I., Hernández-Hierro, J., Revilla, M.I., Vivar-Quintana, A., Lobos-Ortega, I., GonzálezPérez, C. (2009): Changes in the mineral content in cheeses of different compositions during 6 months of ripening. Czech Journal of Food Science 27, S114-S118.

13. Gordon, I. (2014): Minerals and vitamins in milk and dairy products. In: Milk and Dairy Products as Functional Foods, ed A. Kanekanian, John Wiley \& Sons, Ltd, Oxford UK, 289-313. https://doi.org/10.1002/9781118635056.ch9

14. Jaoude, A.D., Olabi, A., El Ouyoun Najm, N., Malek, A., Saadeh, C., Baydoun, E., Toufeili, I. (2010): Chemical composition, mineral content and cholesterol levels of some regular and reduced-fat white brined cheeses and strained yogurt (Labneh). Dairy Science and Technology 90, 699-706. https://doi.org/10.1051/dst/2010026

15. Heck, J.M.L, van Valenberg, H.J.F., Dijkstra, J., van Hooijdonk, A.C.M. (2009): Seasonal variation in the Dutch bovine raw milk composition. Journal of Dairy Science 92 (10), 4745-4755. https://doi.org/10.3168/jds.2009-2146

16. Herrera, M., Peláez, P., Fresno, M., Rodriguez, E., Darias, J., Díaz, C. (2006): Mineral and trace element concentrations of dairy products from goats milk produced in Tenerife (Canary Islands). International Dairy Journal 16, 182-185. https://doi.org/10.1016/j.idairyj.2005.01.011 
17. Jakobsen, M.U., O’Reilly, E.J., Heitmann, B.L., Pereira, M.A., Bälter, K., Fraser, G.E., Goldbourt, U., Hallmans, G., Knekt, P., Liu, S., Pietinen, P., Spiegelman, D., Stevens, J., Virtamo, J., Willett, W.,C., Ascherio, A. (2009): Major types of dietary fat and risk of coronary heart disease: a pooled analysis of 11 cohort studies. American Journal of Clinical Nutrition 89 (5), 1425-1432. https://doi.org/10.3945/ajcn.2008.27124

18. Jenness, R. (1980): Composition and characteristics of goat milk. Review. Journal of Dairy Science 63, 1605-1630. https://doi.org/10.3168/jds.S0022-0302(80)83125-0

19. Jones, J.B.Jr. (2001): Plant analysis. In: Laboratory guide for conducting soil tests and plant analysis. CRC Press. London. 203-207.

20. Jones, J.B.Jr., Case, V.W. (1990): Sampling, handling and analyzing plant tissue samples. In: Soil testing and plant analysis, ed. R.L. Westerman, SSSA Book Series: 3. Soil Sci. Soc. Am. Madison, Wisconsin, USA. 404409.

21. Kanekanian, A. (2014): The health benefits of bioactive compounds from milk and dairy products. In: Milk and Dairy Products as Functional Foods, ed A. Kanekanian, John Wiley \& Sons, Ltd, Oxford UK, 1-22. https://doi.org/10.1002/9781118635056.chl

22. Kostić, A.Ž., Mačukanović-Jocić, M.P., Špirović Trifunović, B.D., Vukašinović, I.Ž., Pavlović, V.B., Pešić, M.B. (2017): Fatty acids of maize pollen - Quantification, nutritional and morphological evaluation. Journal of Cereal Science 77,180-185. https://doi.org/10.1016/j.jcs.2017.08.004

23. Legrand, P., Rioux, V. (2010): The complex and important cellular and metabolic functions of saturated fatty acids. Lipids 45, 941-946. https://doi.org/10.1007/s1 1745-010-3444-x

24. Lock, A.L., Givens, D.I., Bauman, D.E. (2014): Dairy fat: Perceptions and realities. In: Milk and Dairy Products as Functional Foods, Ed. A. Kanekanian, John Wiley \& Sons, Ltd, Oxford UK, 174-192. https://doi.org/10.1002/9781118635056.ch6

25. López-Expósito, I., Amigo, L., Recio, I. (2012): A mini-review on health and nutritional aspects of cheese with a focus on bioactive peptides. Dairy Science and Technology 92, 419-438. https://doi.org/10.1007/s13594-012-0066-5

26. Mallatou, H., Pappa, E., Massouras, T. (2003): Changes in free fatty acids during ripening of Teleme cheese made with ewes', goats', cows' or a mixture of ewes' and goats' milk. International Dairy Journal 13, 211-219. https://doi.org/10.1016/S0958-6946(02)00153-X

27. Markiewicz-Kęszycka, M., Czyżak-Runowska, G., Lipińska, P., Wójt, J. (2013): Fatty acid profile of milk a review. Bull Vet Inst Pulawy 57, 135-139.

28. McSweeney, P.L.H., Sousa, M.J. (2000): Biochemical pathways for the production of flavour compounds in cheese during ripening. A review. Lait 80, 293-324. https://doi.org/10.1051/lait:2000127

29. Mendil, D. (2006): Mineral and trace metal levels in some cheese collected from Turkey. Food Chemistry 96, 532-537. https://doi.org/10.1016/j.foodchem.2005.03.006

30. Moreno-Rojas, R., Amaro-Lopez, M. A., ZuereraCosano, G. (1994). Copper, iron and zinc variations in Manchego-type cheese during the traditional cheese-making process. Food Chemistry 49, 67-72. https://doi.org/10.1016/0308-8146(94)90234-8
31. Nair, M.K.M., Joy, J., Vasudevan. P., Hinckley, L., Hoagland, T.A., Venkitanarayanan, K.S. (2005): Antibacterial effect of caprylic acid and monocaprylin on major bacterial 24 mastitis pathogens. Journal of Dairy Science 88, 3488-3495. https://doi.org/10.3168/jds.S0022-0302(05)73033-2

32. Parodi P. (2009): Has the association between saturated fatty acids, serum cholesterol and coronary heart disease been over emphasized? International Dairy Journal 19, 345-361. https://doi.org/10.1016/j.idairyj.2009.01.001

33. Patińo, E., Faisal, E., Cedres, J., Mendez, F., GuanziroliStefani, C. (2005): Contenido mineral de leche de búfalas (Bubalus bubalis) en Corrientes, Argentina. Revista Veterinaria 16, 40-42.

34. Prandini, A., Sigolo, S., Piva, G. (2011): A comparative study of fatty acid composition and CLA concentration in commercial cheeses. Journal of Food Composition Analysis 24, 55-61. https://doi.org/10.1016/j.jfca.2010.04.004

35. Prieto, B., Franco, I., González, J., Bernardo, A., Carballo, J. (2002): Compositional and physicochemical modifications during the manufacture and ripening of Leon's raw cow milk cheese. Journal of Food Composition and Analysis 15, 725-735. https://doi.org/10.1006/jfca.2002.1055

36. Raynal-Ljutovac, K., Lagriffoul, G., Paccard, P., Guillet, I., Chilliard, Y. (2008): Composition of goat and sheep milk products: An update. Small Ruminant Research 79, 57-72. https://doi.org/10.1016/j.smallrumres.2008.07.009

37. Renner, E. (1987): Nutritional aspects of cheese. In: Cheese: chemistry, physics and microbiology. General aspects, Vol 1. ed Fox P.F., Elsevier Applied Science, London, 345-436. https://doi.org/10.1007/978-94-017-5571-9_20

38. Sanz Sampelayo, M.R., Chilliard, Y., Schmidely, P.H. Boza, J. (2007): Influence of type of diet on the fat constituents of goat and sheep milk. Small Ruminant Research 68, 42-63. https://doi.org/10.1016/j.smallrumres.2006.09.017

39. SEMA. Managment and environmental reclamation plan of baia from BamH to Sapetiba, Vol I, Secretaria de Estado de Meio Ambiente do Rio de Janeiro, 1998, Rio de Janeiro.

40. Yüzbaşi, N., Sezgin, E., Yildirim, M., Yildirim, Z. (2003): Survey of lead, cadmium, iron, copper and zinc in Kasar cheese. Food Additives and Contaminants 20, 464-469. https://doi.org/10.1080/0265203031000094654

41. Yüzbaşi „ N.I., Sezgin, E., Yildirim,Z, Yildirim, M. (2009): Changes in $\mathrm{Pb}, \mathrm{Cd}, \mathrm{Fe}, \mathrm{Cu}$ and $\mathrm{Zn}$ levels during the production of Kasar cheese. Journal of Food Quality 32, 73-83. https://doi.org/10.1111/j.1745-4557.2007.00167.x

42. Ulbricht, T.L., Southgate, D.A. (1991): Coronary heart disease: seven dietary factors. Lancet 19, 985-92. https://doi.org/10.1016/0140-6736(91)91846-M

43. Walstra, P., Jenness, R. (1984): Dairy Chemistry and Physics, John Wiley, New York.

44. Zeppa, G., Giordano, M., Gerbi, V., Arlorio, M. (2003): Fatty acid composition of Piedmont "Ossolano" cheese, Lait 83, 167-173. https://doi.org/10.1051/lait:2003007 